\title{
Character Values Development in Early Childhood through Traditional Games
}

\author{
Serli Marlina \\ Universitas Negeri Padang \\ Corresponding e-mail: serlifipunp@gmail.com
}

\begin{abstract}
The importance development of the character values in early childhood is urgent and necessary today, because the condition of the people who are experiencing a crisis of character. Character values that are developed in early childhood is the love of God, Honesty, Discipline, Tolerance and peaceful , Confidence, Self, mutual help, cooperation, and mutual cooperation, respect and courtesy, responsibility, hard work, leadership and justice, Creative, humble, Care for the environment, nationalism. The traditional games is one method of development of the character values in early childhood.
\end{abstract}

Keywords: character values, traditional games

\section{INTRODUCTION}

Young children is a gift from God that must be guarded and guided well. Children is the generation determinant for the nation's progress. Young children age as the golden age because it is the age to inculcate and develop all children's potential especially the values of kindness. Those values will form the character of the early childhood in order to be accepted by the community.

The development of the character values in early childhood is urgently needed today. Data corruption cases in Indonesia by ACCH (2016) of the year 2004 to 2016 is 386 cases and Waseso describes in Kompas (2016) drug users in June 2015 recorded 4.2 million and in November increased significantly to 5.9 million people. Indonesia is currently experiencing a crisis of character that makes the future generation lost their ways to act. The development of the character values in early childhood is intended to provide solutions to the social problems.

\section{CHARACTER VALUES IN EARLY CHILDHOOD}

\subsection{The Concept of Character}

The General Director of PAUDNI (2012: 4) explain character is the nature of doing good things and a character education instills character values to students which include knowledge, awareness or willpower, and actions to implement the values of goodness and virtue, to the God almighty, themselves, and others. Poerwadarminta (2003: 1364) describes the character as the inner nature of men that affects all thoughts and actions, nature or character, and it also distinguishes one person to another. According to Adisusilo (2012: 76), characters are traits to be admired as a sign of wisdom, kindness and moral maturity. Someone who has a good character will always behave well, pleasant, and wise in making decisions that are needed in social life.

\subsection{Value Characters in Early Childhood}

Developing good values at an early age is like carving on a stone because the development of the 
virtues has to be done and planned since the beginning. The development of the character values in early childhood is done through moral education. Lickona describes four stages in moral education which are knowing, reasoning, feeling and acting. Meanwhile, the General Director of PAUDNI (2012: 5) states that in the early childhood, values education is considered very important to be introduced and internalized into the children's behavior including; 1) the love of God Almighty, 2) honesty, 3) discipline, 4) tolerance and peace, 5) confidence, 6) independent, 7) mutual help, 8) cooperation, 9) responsibility, 10) hard work, 11) leadership and justice, 12) creative, 13) humble, 14) environmental care and 15) nationalism.

The values of character education can be taught in early childhood (0-6 years). It includes four aspects: (1) spiritual aspects, (2) personal aspects/personality, (3) social aspects, and (4) environmental aspects. The character education involves knowledge, love, and kindness which can later become a habit. The character education cannot be separated from the good baseline values.

The development of the character values represents a system of character values development to the school community which includes knowledge, awareness, willingness and action to implement these values well toward the God Almighty and themselves. The educational process humanizes the people. It takes time in order to be able to analyze its impacts and effectiveness. Therefore, educators and parents need to be more patient, more aware, and better understand that it takes a time to develop the character values to children. As a result, positive values are internalized from those which are obtained at school and at home.

The goals of the character values development can be divided into personal changes and changes in the institution. Personal changes form the individuals to have strong characters that cannot easily be swept away by the negative effects and become the examples to the people in the surroundings. Individuals with strong characters will eventually form the environment to have a wellbalanced culture that is born from the positive character and will also form every educational institution into school culture and family culture.

\subsection{The Principles of Character Values Development from the Early Age}

The development of the character values at the early age should be done in a routine and integrated into every aspect. This development is done in a sustainable manner by giving examples and role models, creating an atmosphere of mutual love, always motivating the children, always being in collaboration with the child in any action relating to his or her development and being democratic. The General Director of PAUDNI (2012: 5-6)

emphasizes seven principles of character education from the early age. They are:

a. It is given by examples and exemplary.

b. It is sustainable.

c. It is comprehensive and is integrated into all aspects of development.

d. It creates an atmosphere of affection.

e. It motivates the children.

f. It involves teachers and education personnel, parents, and community.

g. It includes an evaluation process

The principles are developed through all aspects of the development activities in the early childhood and are done in a fun method.

\section{TRADITIONAL GAMES IN THE EARLY CHILDHOOD}

\subsection{Early Childhood Games}

Games provide various forms of activities for children which are not too serious, flexible, and the materials contained in the toys are imaginatively transformed along with the adult world. According to Hurlock (1978: 320), games undertake all the pleasure activities regardless of the final result. It is voluntary and there is no coercion or pressure from the outsiders. Hurlock also mentions Piaget's opinion on the definition of games. Piaget explains that games are repetitive activities for a functional pleasure. Bettelheim in Hurlock describes games as activities that do not have rules. The rules are made by the player himself and there is no end result that is intended in the reality.

Sujiono (2009: 86) cites the opinion of Mayesty (1990: 196-197) who explains that for children, games are their activities throughout the day. For them, games mean life and vice versa. Vygotsky believes that games develop the children's cognitive directly, not just as a result of cognitive development as proposed by Piaget. Playing games is needed by younger children since it is a part of their life. Games provide pleasure for them so that they can express their feelings by playing games.

For children, playing games is a way to transform a potential force as well as a mean of channeling their energy. Jeffree, McConkey and Hewson as cited in Sujiono (2009: 146) describes the general characteristics of playing games in childhood period. They are: 
a. it emerges from the inner part of the children.

b. it should be free of binding rules, the activities are to be enjoyed.

c. it is a real or actual activity.

d. it should focus on the process rather than the results.

e. it should be dominated by the players.

f. it should involve the active participation of the players.

In line with the above opinion, Hartati (2005:

11) points out the characteristics of play are:

a. Playing is done because volunteerism is not coercion

b. Playing is an activity to be enjoyed are always fun, exciting

c. Playing is done without any lure for play. The activity itself is fun d. Playing more will prioritize the activities of the destination

d. Playing requires the active participation both physically and psychically

e. Playing is free-rules

f. Playing is spontaneous in accordance with the desired time

g. Meaning and pleasure of playing are determined by children.

The modest opinion expressed by Schwartz (in Hartati, 2005: 85-86), according to the

characteristics of the play is an interesting thing, the play is open, imaginative and creative.

Characteristics playing for early childhood is a freedom that is free of rules as well as imaginative and creative, spontaneous, but it has no meaning in the lives of children. Something with the purpose of playing which is a demand and need for early childhood development, the purpose of playing according to the Ministry of Education (2002: 56) are:

a. Can develop the intellect (Cognitive) children to be able to link the knowledge that is already known to the knowledge acquired

b. Train the child's language ability to be able to communicate verbally with the environment

c. Train the children's skills in order to develop fine motor skills

d. Children to develop physical motor skills base in the body amend useful for healthy growth

e. Developing creativity of children to be creative, smooth, flexible and original

f. Improving children's emotional sensitivity by introducing an assortment of feelings and foster self-confidence

g. Develop social skills such as developing relationships with other children, with behavior in accordance with the demands of society and can adapt to a friend.

Frank and Theresa (in Moeslichatoen, 2004: 24-25) suggest the value of playing for children: Playing helps the growth of children, playing is an activity that is carried out voluntarily, playing gives children's freedom to act, playing gives imaginary world that can be mastered, play has an element of adventure in it, playing laid the foundation for language development, play has a unique influence in the formation of interpersonal relations. Playing provides an opportunity to take control of yourself physically. Playing expands interest and concentration of attention, Playing is the way children to investigate something, Playing is the way children learn about the role of adults, Playing is a dynamic way to learn, playing is clear consideration of the child, playing can be structured in academic. Playing is the life force, and playing is essential to the survival of humankind.

Playing has an important purpose for the growth and development of all aspects of the child both the development of cognitive, affective, physical, motor, social or religious and moral development of children. Therefore, great value plays in the lives of children, the use of play activities in the development of the character value is an absolute requirement that absolutely can't be ignored.

\subsection{Development of Character Values in Early Childhood through Traditional Games}

\subsubsection{The Marbles Hole game}

This game was often played by children in Indonesia in the past. In West Sumatera This game will be played by a minimum of two people and can be played by many people. Before the game begins, the player makes 3 holes, a distance of one hole to another hole is measured with the player's footsteps. The level of difficulty in playing is determined by the distance of footsteps and the average of the player's ability. This decision is taken in deliberation by the player. Players also deliberate the queue of players in play. The game is played, firstly players send the marbles with a scolding finger to the first oke, then, to the second hole and it is continued the next in the hole. This can be done if the player manages to insert marbles into the hole. If not able to insert marbles into the hole then the next player can continue the game and the player can get rid of the first player with by flicking the first players to 
make it away from the hole. The game will continue until it finds a player who comes to the last hole and becomes a winner in this game. The process of these games trains 1) the love of God Almighty, 2) honesty, 3) discipline, 4) tolerance and peace, 5) confidence, 6) independent, 7) mutual help, 8) cooperation, 9) responsibility, 10) hard work, 11) leadership and justice, 12) creative, 13) humble, 14) environmental care and 15) nationalism. Based on the above development of the character values can be developed through Traditional Games.

\subsubsection{The game Galah Panjang or Cak Bur}

Played by two teams in one arena called the arena, usually created by drawing a line on the ground with a size of about $2 \times 2$ meters which is divided into several boxes, but the size is not standard, but can be customized. Two teams playing will fight to have the same number of members. One team plays as a guard and the team again as a player. The task team as the player is passed through the boxes there to get to the end and back again to the beginning without be touched by the guards. The game begins by saying "smack" by guards the front line and ending with the words "Bur" by players who made it through the arena that signifies victory. The game is repeated until all team members managed to escape, but when touched, the team must turn in the case. This game can exercise patience, perseverance, honesty, tolerance and peaceful, Confidence, Self, please help, cooperation, responsibility, hard work, leadership and Justice, Creative, Humility, love of the nation and homeland.

\subsection{Traditional Games as Character Value Method Development in Early Childhood}

The traditional game is a game played by children in the past, where the game was conventional. The game is always done together both indoors and outdoors. The game is always played in groups and played by two or more people. The findings of research done by Kurniati (2011: 13) in Haerani (2013: 89) indicates that the traditional game can stimulate children in developing cooperation, help the child adjust to, interact in a positive, can condition the child in self-control, develop empathy towards friends, obey the law, and respect for others. The conclusions of the findings was that traditional games can develop character values in early childhood. This development occurs in the process of playing fun for children.
Ernita (2012: 3), in line with Purwaningsih's opinion (2006) traditional game contains elements of cultural values. According to Dharmamulya (2008), elements of cultural values embodied in the traditional game are the value of pleasure or excitement, the value of freedom, friends, democratic values, values of leadership, a sense of responsibility, the value of togetherness and mutual support, the value of obedience, train proficient in numeracy, thinking skills training, the value of honesty and sportsmanship. Ernita research results (2012) also proves that the traditional game of Java in this study effectively used to build the character of honesty in early childhood.

\section{CONCLUSIONS}

The development of the character value is the solution of problems of the nation today. Development efforts undertaken character starts from an early age. The values of character education at an early age include (1) Spiritual Aspects, (2) Personal Aspects / personality, (3) Social Aspects, and (4) the environmental aspect. Development of the value of the character at an early age is done through play, because play had a learning tool in accordance with an early age. The traditional game is a game is much loved child. In the traditional game takes at least two children in the play. Traditional game types used in the development of the character value is a game of Marbles Hole game and Galah Panjang. The game was selected to develop the character values because this game requires 1) the love of God Almighty, 2) honesty, 3) discipline, 4) tolerance and peace, 5) confidence, 6) independent, 7) mutual help, 8) cooperation, 9) responsibility, 10) hard work, 11) leadership and justice, 12) creative, 13) humble, 14) environmental care and 15) nationalism. The game is very relevant to the character values that need to be developed.

\section{ACKNOWLEDGEMENTS}

Thank you very much for Universitas Negeri Padang and Majoring in teacher education for early childhood education.

\section{REFERENCES}

\section{ACCH. (2016). Rekapitulasi Penindakan Pidana Korupsi. Retrieved from http://acch.kpk.go.id/statistik.}

Adisusilo, Pranoto. (2012). Pembelajaran Karakter Pada Anak. Jakarta. Gaung Persada Press. 
Dirjen PAUDNI. (2012). Pedoman Pendidikan Karakter Pada Pendidikan Anak Usia Dini. Jakarta.

Ernita, Lusiana. (2012). Membangun pemahaman karakter kejujuran melalui Permainan tradisional pada anak usia dini di Kota Pati. Retrieved from.

http://journal.unnes.ac.id/sju/index.php/belia/a rticle/download/1601/1531

Haerani, Nur. (2013). Membangun Karakter Anak Melalui Permainan Anak Tradisional.Retrieved from.http://journal.uny.ac.id/index.php/jpka/art icle/download/1290/1074

Hurlock, Elizabeth B. (1978). Perkembangan Anak. Jakarta: Erlangga. Translation by dr. Med. Meitasari Tjandrasa dan Dra. Muslichah Zakarsih.

Kompas. (2016, January 11). Buwas: Pengguna Narkoba di Indonesia Meningkat hingga 5,9 Juta Orang. Retrieved from. http://regional.kompas.com/read/2016/01/11/14 313191/Buwas.Pengguna.Narkoba.di.Indonesia .Meningkat.hingga.5.9.Juta.Orang.

Moeslichatoen. (2004). "Metode Pengajaran Di Taman Kanak-kanak". Jakarta: Asdi Mahasatya Poerwadarminta. 2003. Kamus Bahasa Indonesia. Jakarta. Balai Pustaka. Pusat Bahasa. Departemen Pendidikan Nasional.

Sujiono, Yuliani Nurani. (2009). Konsep Dasar Pendidikan Anak Usia Dini. Jakarta: PT. Indeks 